Research article

\title{
The angiogenesis inhibitor protease-activated kringles 1-5 reduces the severity of murine collagen-induced arthritis
}

\author{
Percy F Sumariwalla ${ }^{1}$, Yihai $\mathrm{CaO}^{2}$, Hua-Lin Wu${ }^{3}$, Marc Feldmann ${ }^{1}$ and Ewa M Paleolog${ }^{1}$
}

\author{
${ }^{1}$ Kennedy Institute of Rheumatology Division, Faculty of Medicine, Imperial College of Science, Technology and Medicine, London, UK \\ ${ }^{2}$ Laboratory of Angiogenesis Research, Microbiology and Tumor Biology Center, Karolinska Institute, Stockholm, Sweden \\ ${ }^{3}$ Department of Biochemistry, National Cheng Kung University Medical College, Taiwan, Republic of China \\ Corresponding author: Dr Ewa Paleolog (e-mail: e.paleolog@ic.ac.uk)
}

Received: 10 July 2002 Revisions received: 27 September 2002 Accepted: 2 October 2002 Published: 31 October 2002

Arthritis Res Ther 2003, 5:R32-R39 (DOI 10.1186/ar608)

(c) 2003 Sumariwalla et al., licensee BioMed Central Ltd (Print ISSN 1478-6354; Online ISSN 1478-6362). This is an Open Access article: verbatim copying and redistribution of this article are permitted in all media for any non-commercial purpose, provided this notice is preserved along with the article's original URL.

\begin{abstract}
During rheumatoid arthritis there is enlargement and increased cellularity of the synovial lining of joints, before invasion by the synovium of the underlying cartilage and bone. This increased tissue mass requires a network of blood vessels to supply nutrients and oxygen. Disruption of synovial angiogenesis is thus a desirable aim of antiarthritic therapies. Protease-activated kringles $1-5(\mathrm{~K} 1-5)$ is an angiogenesis inhibitor related to angiostatin. In common with angiostatin, $\mathrm{K} 1-5$ contains the first four kringle domains of plasminogen, but also encompasses the kringle 5 domain, which confers enhanced antiangiogenic activity when compared with angiostatin. The purpose of the present study was to assess the effect on murine arthritis of

$\mathrm{K} 1-5$. Arthritis was induced in DBA/1 mice by a single injection of bovine collagen. Treatment with $\mathrm{K} 1-5$ was commenced on the day of arthritis onset and continued for 10 days, until the end of the experiment. Daily intraperitoneal administration of $\mathrm{K} 1-5$ ( $2 \mathrm{mg} / \mathrm{kg}$ body weight) significantly reduced both paw swelling and clinical score (a composite index of the number of arthritic limbs and the severity of disease). The clinical efficacy of this treatment was reflected by a reduction in joint inflammation and destruction, as assessed histologically. These data suggest that antiangiogenic therapies, which block formation of new blood vessels and hence reduce synovial expansion, might be effective in treating rheumatoid arthritis.
\end{abstract}

Keywords: angiogenesis, arthritis

\section{Introduction}

Inflammatory joint diseases such as rheumatoid arthritis (RA) are a major cause of disability, and are frequently associated with increased morbidity and mortality. A hallmark feature of RA is chronic inflammation and hyperplasia of the synovial lining of joints. The expanding synovial tissue invades and subsequently destroys the underlying cartilage and bone. Increased cellularity is also observed within both the synovial fluid and synovial membrane, which is due to recruitment and retention of cells from the blood, including macrophages, $\mathrm{T}$ cells and dendritic cells [1].

The enlarged synovium imposes an increased demand for nutrients and oxygen. A hallmark of RA is thus an increased rate of formation of new blood vessels ('angiogenesis') [2-4]. Many proangiogenic mediators are expressed in RA, including vascular endothelial growth factor (VEGF). VEGF is expressed in RA synovium [5-7], and levels of VEGF are upregulated in the serum of RA patients $[8,9]$. These observations suggest that angiogenesis is an important event during the development of RA. Paradoxically, however, in spite of the increased rate of endothelial proliferation and expression of molecules such as VEGF, angiogenesis may not keep pace with synovial hyperplasia, resulting in areas of hypoxia [10]. This hypoxic state stimulates the production of angiogenic factors and further perpetuates new blood vessel formation. Targeting the vasculature in RA is thus a potential therapeutic approach in RA [11,12]. 
Several broadly acting angiogenesis inhibitors, such as paclitaxel, TNP-470 and thalidomide, have been shown to inhibit pannus formation and neovascularization in animal models of arthritis [13-18]. Recently, more specific antiangiogenic approaches have been employed. For example, our group reported that a soluble form of the Flt1 VEGF receptor significantly reduced disease severity and joint destruction in murine collagen-induced arthritis (CIA) [19]. The effectiveness of VEGF blockade in CIA was also shown in further studies using anti-VEGF polyclonal antibodies $[20,21]$. These examples support the concept that antiangiogenic therapies may be a potentially useful tool in the treatment of arthritis.

In addition to blocking the activity of proangiogenic molecules such as VEGF, an alternative approach would be to utilize known inhibitors of angiogenesis [22]. One such potent angiogenesis inhibitor is angiostatin, which is generated as a result of proteolytic cleavage of plasminogen and comprises the first four triple loop disulphide-linked structures of plasminogen, termed kringle domains $[23,24]$. Characterization of the inhibitory activity of kringle (K) fragments of angiostatin demonstrated that $\mathrm{K} 1, \mathrm{~K} 2$ and $\mathrm{K} 3$, but not K4, inhibited endothelial cell proliferation, whereas a structure combining $\mathrm{K} 1-3$ was more effective than $\mathrm{K} 1-4$ (equivalent to angiostatin) [25]. A subsequent study revealed that the $\mathrm{K} 5$ proteolytic fragment of human plasminogen is an even more potent inhibitor of endothelial proliferation [26]. Urokinase-activated plasmin can also convert plasminogen into a molecule containing the intact $\mathrm{K} 1-4$ and most of the K5 domains, termed $\mathrm{K} 1-5$. That angiogenesis inhibitor inhibited endothelial cell proliferation more effectively than did angiostatin. Moreover, $\mathrm{K} 1-5$ treatment suppressed tumour growth and neovascularization in mice carrying a primary fibrosarcoma [27].

The effectiveness of $\mathrm{K} 1-5$ treatment in the mouse tumour model prompted us to examine the effects of this inhibitor in murine $\mathrm{CIA}$, which has several similarities with RA, including synovitis, pannus formation, erosion of cartilage and bone, fibrosis and joint rigidity. The relevance of this model has been demonstrated using anti-tumour necrosis factor (TNF)- $\alpha$ antibody, which was first used to ameliorate CIA [28], and was subsequently proven to be clinically effective for the treatment of human RA [29]. In the present study we observed that systemic administration of K1-5 markedly reduced clinical and pathological features of established CIA. This was accompanied by a significant reduction in the histological features of disease. These data indicate that antiangiogenic therapies could have potential applications in the management of RA.

\section{Materials and method}

\section{Induction and assessment of arthritis}

Ten-week-old, inbred, male DBA/1 ( $\mathrm{H}-2 \mathrm{q})$ mice (Harlan UK Limited, Oxon, UK) received a single intradermal injection of $100 \mu \mathrm{l}$ bovine type II collagen [30] emulsified in complete Freund's adjuvant (Difco, Detroit, MI, USA) at the base of the tail. The first clinical signs of arthritis, as assessed by oedema and/or erythema involving any of the paws, appeared between days 14 and 28 after immunization, with a mean onset of arthritis at day 21 after immunization.

Mice were monitored daily and each limb was given a clinical score as follows: 0 , normal paws and no clinical features of inflammation; 1, slight oedema or erythema; 1.5, oedema and erythema involving at least some digits; 2, frank oedema/erythema involving the entire paw; and 2.5, pronounced oedema and erythema leading to incapacitated limb mobility. Each limb was graded in this manner, giving a maximum possible score of 10 per mouse. All hind paws were measured daily to record the degree of paw thickness, using a fine engineer's calliper (least count $0.1 \mathrm{~mm}$; Röhm GB Ltd, Kingston-Upon-Thames, UK). Mice were humanely killed on day 10 of disease. Data are expressed as mean ( \pm SEM) clinical score or paw thickness. Alternatively, data are expressed as the increase in clinical score or paw thickness from day 1 of arthritis.

\section{Preparation and in vivo administration of protease-activated kringles 1-5}

K1-5 was prepared by urokinase-activated plasmin-mediated digestion of amino-terminal Glu'-plasminogen, as previously described [27]. The purified $\mathrm{K} 1-5$ was analyzed using amino-terminal and carboxyl-terminal sequencing, and stored diluted in phosphate-buffered saline (PBS) at $-80^{\circ} \mathrm{C}$ before use.

In order to assess the effect of $\mathrm{K} 1-5$ on established CIA, treatment was commenced from the first day of the onset of the clinical symptoms of arthritis, which was considered to be the day when the first visible signs of erythema and/or oedema were observed in any of the limbs. Mice were randomly selected and assigned to one of the following groups: no treatment, vehicle (equal volume of PBS, $\mathrm{pH}$ 7.2), or $\mathrm{K} 1-5$. The route of delivery was intraperitoneal administration, at doses of either $0.2 \mathrm{mg} / \mathrm{kg}$ body weight or $2 \mathrm{mg} / \mathrm{kg}$ body weight. Treatments were given daily for a period of 10 days. Assessments of clinical score and paw thickness were performed by an observer who was unaware of the treatment group to which the animals had been assigned.

\section{Histological assessment}

Hind feet were removed after death and fixed using 4.5\% buffered formalin. One week later, hind feet were decalcified in buffered formalin containing 5.5\% EDTA. Upon decalcification, paws were embedded in paraffin wax blocks, sectioned, and stained with haematoxylin and eosin for microscopic evaluation, which was performed by an observer who was blinded to the treatments received. 
Each section was screened for changes to the joint architecture and every joint was scored as follows: normal, mild (minimal synovitis, some cartilage loss, shrinkage in the size of cartilage chondrocytes with denucleation, and bone erosions limited to discrete foci), moderate (more extensive synovial hyperplasia, destruction of large segments of the cartilage and considerable bone erosions caused by an invasive pannus front) and severe (complete destruction of the joint architecture).

\section{Measurement of antibovine collagen type II IgG}

Blood samples were collected from mice on day 10 of arthritis by exsanguination following terminal cardiac puncture. The blood was allowed to clot at room temperature for 1 hour followed by incubation at $4^{\circ} \mathrm{C}$ overnight to separate the serum, which was aliquoted and stored at $-20^{\circ} \mathrm{C}$.

To assay the serum levels of total antibovine collagen type II lgG, microtitre plates were coated with $2 \mu \mathrm{g} / \mathrm{ml}$ of purified bovine collagen type $I I$ in Tris-buffered saline overnight at $4^{\circ} \mathrm{C}$. The plates were blocked with $2 \%$ bovine serum albumin in PBS and incubated with serum at $4^{\circ} \mathrm{C}$ overnight. Bound IgG was detected with alkaline phosphatase conjugated goat antimouse IgG (Sigma, Poole, Dorset, UK) followed by p-nitrophenyl phosphate. Absorbance was determined at $405 \mathrm{~nm}$. To quantify antibovine collagen lgG, pooled serum from mice killed on day 10 of arthritis ( $n=6$; arthritis clinical score 10) was assigned an arbitrary value of $100 \mathrm{units} / \mathrm{ml}$.

\section{Statistical analyses}

Data were analyzed using the Graph Pad Prism software package (Graph Pad Software, San Diego, CA, USA). Two-way analysis of variance was used to compare effect of different treatments on the clinical scores and paw thickness. One-way analysis of variance with NewmanKeul post-test for multiple comparisons was used to compare serum anticollagen IgG levels. The statistical significance of histology data was evaluated by comparing the number of sections that were either normal, or exhibited mild, moderate or severe changes, using $\chi^{2}$ test for trends. Data from individual experiments were analyzed separately, although the same trend was seen in all of three experiments.

\section{Results}

Protease-activated kringles 1-5 significantly reduces disease severity in murine collagen-induced arthritis

To determine the effect of $\mathrm{K} 1-5$ on $\mathrm{CIA}$, treatment was commenced on the first day of arthritis. Animals were treated with $\mathrm{K} 1-5$ and compared with those administered PBS as the vehicle control. A control group of animals was left untreated.

In a total of three experiments, intraperitoneal administra- every day until day 10 markedly reduced the severity of CIA. A typical experiment is illustrated in Table 1, which shows the absolute values for the clinical scores (a composite index of disease severity and the number of limbs affected) and the paw thickness. In order to normalize the data, these parameters were also expressed as change from day 1 of disease (Figs 1 and 2). For example, untreated mice exhibited a mean increase in paw thickness by day 4 of disease of $0.42 \pm 0.09 \mathrm{~mm}$, as compared to $0.01 \pm 0.06 \mathrm{~mm}$ for animals that received $\mathrm{K} 1-5$. By day 10 of arthritis, untreated or vehicle-treated mice exhibited mean paw swelling of $0.49 \pm 0.11 \mathrm{~mm}$ and $0.50 \pm 0.09 \mathrm{~mm}$, respectively, as compared with $0.26 \pm 0.13 \mathrm{~mm}$ for animals receiving daily intraperitoneal administration of $2 \mathrm{mg} / \mathrm{kg} \mathrm{K} 1-5 \quad(P<0.001$, versus untreated or vehicle-treated animals). Similarly, the mean increase in clinical score by day 4 of disease was $2.50 \pm 0.54$ for untreated mice, but only $0.25 \pm 0.63$ for mice treated with $\mathrm{K} 1-5$. On day 10 the mean increase in clinical score was $3.00 \pm 0.55$ and $4.00 \pm 1.09$ for untreated and vehicle-treated mice, but only $1.30 \pm 0.78$ for mice treated with $\mathrm{K} 1-5(P<0.001$, versus untreated or vehicle-treated animals). The effect of $\mathrm{K} 1-5$ was dose dependent, in that $0.2 \mathrm{mg} / \mathrm{kg}$ ( $4 \mu \mathrm{g}$ per mouse) every day until day 10 was without significant effect on CIA progression (increase in clinical score on day 10 of arthritis $4.00 \pm 1.06$ [Fig. 1], paw swelling on day 10 of arthritis $0.49 \pm 0.10 \mathrm{~mm}$ [Fig. 2]). Comparable data were obtained in all three experiments.

In order to further assess the effect of in vivo $\mathrm{K} 1-5$ treatment, we measured serum levels of antibovine type II collagen antibodies on day 10 of arthritis. Administration of K1-5 did not affect the total serum levels of antibovine collagen IgG (Fig. 3).

\section{Protease-activated kringles 1-5 decreases joint inflammation and destruction in collagen-induced arthritis}

In order to determine the effect of treatment with $\mathrm{K} 1-5$ on synovial inflammation and bone destruction in CIA, sections from untreated animals, and animals treated with vehicle and K1-5 (sacrificed on day 10 of arthritis) were graded in a blinded manner. The percentages of joints that exhibited normal, mild, moderate or severe changes in bone/cartilage and synovitis were calculated.

A representative experiment is illustrated in Table 2 and Fig. 4. Each joint (distal phalanx joint, proximal phalanx joint, first metatarsal joint and tarsus) was first assessed separately (Table 2). The most apparent differences were observed in the distal phalanx and proximal phalanx joints. In animals treated with $2 \mathrm{mg} / \mathrm{kg} \mathrm{K} 1-5$ there were fewer severely affected joints and an increase in the number of joints in which the cartilage and bone architecture at joint interfaces appeared normal relative to control animals. For 
Table 1

Effect of protease-activated kringles 1-5 treatment on clinical score and paw thickness

\begin{tabular}{|c|c|c|c|c|}
\hline Day of arthritis & Untreated & Vehicle & $\mathrm{K} 1-50.2 \mathrm{mg} / \mathrm{kg}$ & $\mathrm{K} 1-52 \mathrm{mg} / \mathrm{kg}$ \\
\hline \multicolumn{5}{|l|}{ Clinical score } \\
\hline 1 & $2.38 \pm 0.26^{\star \star}$ & $2.22 \pm 0.28^{\star *}$ & $2.50 \pm 0.19^{\star *}$ & $2.57 \pm 0.20$ \\
\hline 2 & $4.08 \pm 0.54^{\star \star}$ & $3.36 \pm 0.43^{\star \star}$ & $3.64 \pm 0.40^{\star \star}$ & $2.33 \pm 0.17$ \\
\hline 3 & $4.71 \pm 0.47^{\star \star}$ & $3.93 \pm 0.48^{\star \star}$ & $4.29 \pm 0.52^{\star \star}$ & $2.14 \pm 0.18$ \\
\hline 4 & $4.93 \pm 0.69^{\star \star}$ & $4.11 \pm 0.52^{\star \star}$ & $4.93 \pm 0.44^{\star \star}$ & $2.75 \pm 0.75$ \\
\hline 5 & $5.29 \pm 0.62^{\star \star}$ & $4.44 \pm 0.54^{\star *}$ & $5.19 \pm 0.58^{\star \star}$ & $3.25 \pm 0.51$ \\
\hline 6 & $5.00 \pm 0.45^{\star \star}$ & $4.89 \pm 0.54^{\star \star}$ & $5.70 \pm 0.44^{\star *}$ & $3.75 \pm 0.51$ \\
\hline 7 & $5.57 \pm 0.47^{\star \star}$ & $5.33 \pm 0.82^{\star \star}$ & $5.67 \pm 1.17^{\star \star}$ & $4.33 \pm 0.38$ \\
\hline 8 & $5.63 \pm 0.45^{\star \star}$ & $5.00 \pm 0.65^{\star \star}$ & $5.56 \pm 0.95^{\star \star}$ & $3.33 \pm 0.38$ \\
\hline 9 & $5.31 \pm 0.59^{\star \star}$ & $6.50 \pm 0.79^{\star \star}$ & $5.75 \pm 0.85^{\star \star}$ & $4.00 \pm 0.64$ \\
\hline 10 & $5.60 \pm 0.68^{\star \star}$ & $5.81 \pm 0.98^{\star \star}$ & $6.50 \pm 1.03^{\star \star}$ & $3.90 \pm 0.91$ \\
\hline \multicolumn{5}{|c|}{ Paw thickness (mm) } \\
\hline 1 & $1.93 \pm 0.04^{\star \star}$ & $1.88 \pm 0.06^{*}$ & $1.94 \pm 0.06^{\star *}$ & $1.91 \pm 0.04$ \\
\hline 2 & $2.20 \pm 0.11^{\star \star}$ & $2.05 \pm 0.08^{\star}$ & $2.11 \pm 0.11^{\star \star}$ & $1.96 \pm 0.08$ \\
\hline 3 & $2.25 \pm 0.11^{\star \star}$ & $2.11 \pm 0.11^{\star}$ & $2.19 \pm 0.10^{\star \star}$ & $1.91 \pm 0.09$ \\
\hline 4 & $2.36 \pm 0.13^{\star \star}$ & $2.19 \pm 0.10^{\star}$ & $2.30 \pm 0.13^{\star \star}$ & $1.92 \pm 0.10$ \\
\hline 5 & $2.34 \pm 0.14^{\star \star}$ & $2.22 \pm 0.12^{\star}$ & $2.33 \pm 0.10^{\star \star}$ & $2.14 \pm 0.13$ \\
\hline 6 & $2.22 \pm 0.14^{\star \star}$ & $2.25 \pm 0.12^{\star}$ & $2.47 \pm 0.12^{\star \star}$ & $2.16 \pm 0.12$ \\
\hline 7 & $2.49 \pm 0.11^{\star \star}$ & $2.23 \pm 0.14^{\star}$ & $2.50 \pm 0.12^{\star \star}$ & $2.21 \pm 0.12$ \\
\hline 8 & $2.43 \pm 0.12^{\star \star}$ & $2.33 \pm 0.12^{*}$ & $2.41 \pm 0.11^{\star \star}$ & $2.20 \pm 0.12$ \\
\hline 9 & $2.37 \pm 0.12^{\star \star}$ & $2.40 \pm 0.09^{\star}$ & $2.41 \pm 0.10^{\star \star}$ & $2.20 \pm 0.11$ \\
\hline 10 & $2.45 \pm 0.15^{\star \star}$ & $2.40 \pm 0.09^{\star}$ & $2.42 \pm 0.11^{\star *}$ & $2.19 \pm 0.16$ \\
\hline
\end{tabular}

From the day of arthritis onset, mice were treated intraperitoneally each day with either vehicle (phosphate buffered saline [PBS]), proteaseactivated kringles $1-5(\mathrm{~K} 1-5)$ at a dose of either $0.2 \mathrm{mg} / \mathrm{kg}$ or $2 \mathrm{mg} / \mathrm{kg}$, or were left untreated. The absolute values for clinical scores and paw thickness are shown. Data were analyzed by two-way analysis of variance: ${ }^{\star} P<0.01,{ }^{\star \star} P<0.001$, versus mice treated with $2 \mathrm{mg} / \mathrm{kg} \mathrm{K1-5}$; all other values $P>0.10$. For numbers of mice in each group, see the legends to Figs 1 and 2 .

\section{Figure 1}

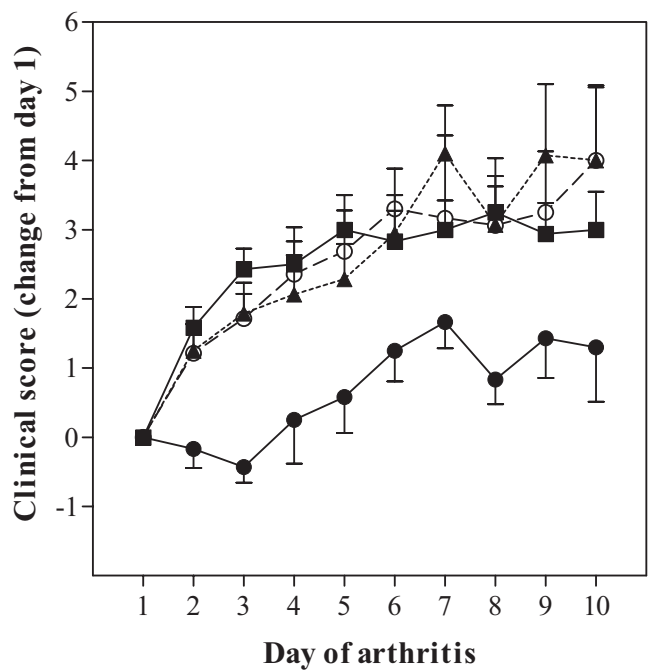

Treatment with protease-activated kringles 1-5 (K1-5) significantly reduces the severity of collagen-induced arthritis. From the day of arthritis onset, mice were treated intraperitoneally each day with $(\boldsymbol{\Lambda})$ vehicle ( $n=9),(\bigcirc) \mathrm{K} 1-5$ at a dose of $0.2 \mathrm{mg} / \mathrm{kg}(n=8)$ or $(\bigcirc) \mathrm{K} 1-5$ at a dose of $2 \mathrm{mg} / \mathrm{kg}(n=8)$, or $(\square)$ were left untreated $(n=8)$. The clinical score is expressed as change from day 1 (mean \pm SEM). Data were analyzed by two-way analysis of variance: $P<0.001$ for mice treated with $2 \mathrm{mg} / \mathrm{kg} \mathrm{K} 1-5$, versus untreated mice, and mice treated with vehicle or $0.2 \mathrm{mg} / \mathrm{kg} \mathrm{K} 1-5 ; P>0.10$ for untreated and vehicletreated mice, versus mice treated with $0.2 \mathrm{mg} / \mathrm{kg} \mathrm{K} 1-5$.
Figure 2

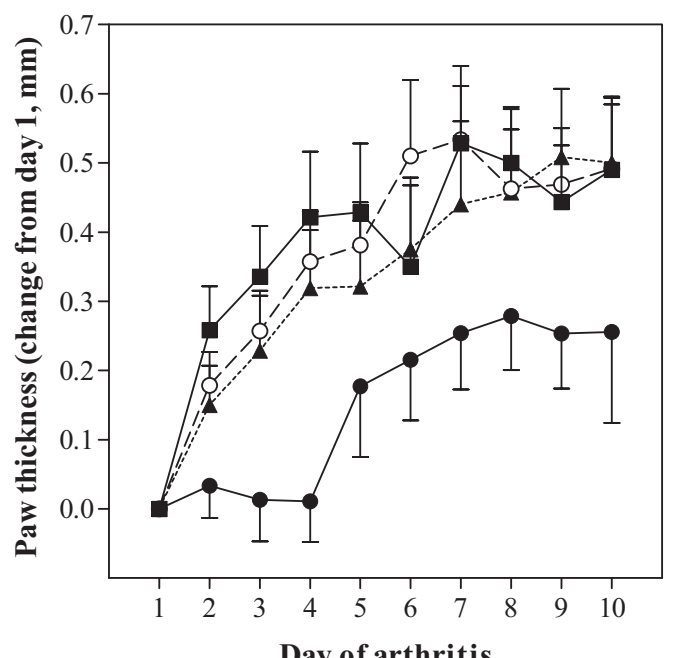

Treatment with protease-activated kringles 1-5 (K1-5) significantly reduces paw swelling in collagen-induced arthritis. From the day of arthritis onset, mice were treated intraperitoneally each day with $(\boldsymbol{\Delta})$ vehicle $(n=9),(\bigcirc) \mathrm{K} 1-5$ at a dose of $0.2 \mathrm{mg} / \mathrm{kg}(n=8)$ or $(-) \mathrm{K} 1-5$ at a dose of $2 \mathrm{mg} / \mathrm{kg}(n=8)$, or $(\square)$ were left untreated $(n=8)$. Paw thickness is expressed as change from day 1 (mean \pm SEM). Data were analyzed by two-way analysis of variance: $P<0.001$ for mice treated with $2 \mathrm{mg} / \mathrm{kg} \mathrm{K} 1-5$, versus untreated mice, and mice treated with vehicle or $0.2 \mathrm{mg} / \mathrm{kg} \mathrm{K} 1-5 ; P>0.10$ for untreated and vehicletreated mice, versus mice treated with $0.2 \mathrm{mg} / \mathrm{kg} \mathrm{K} 1-5$. 
Figure 3

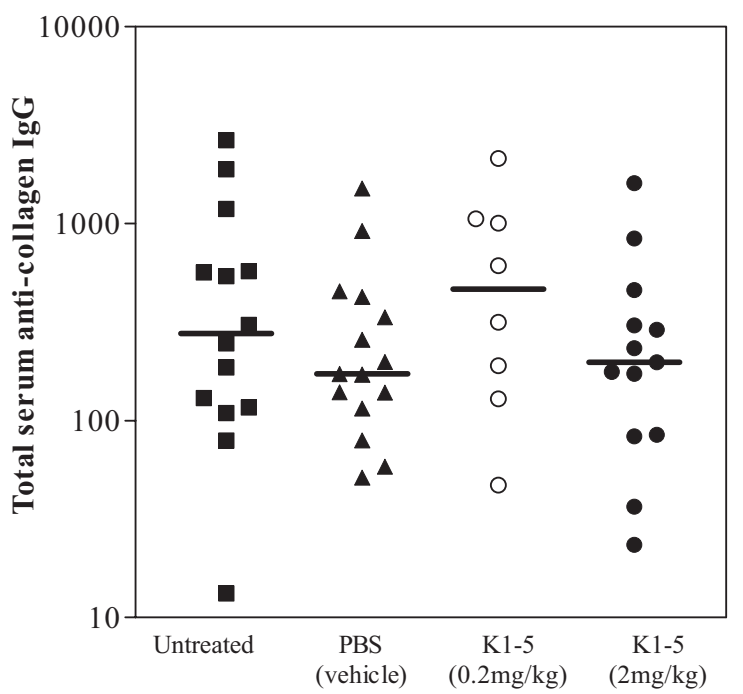

Treatment groups
Figure 4

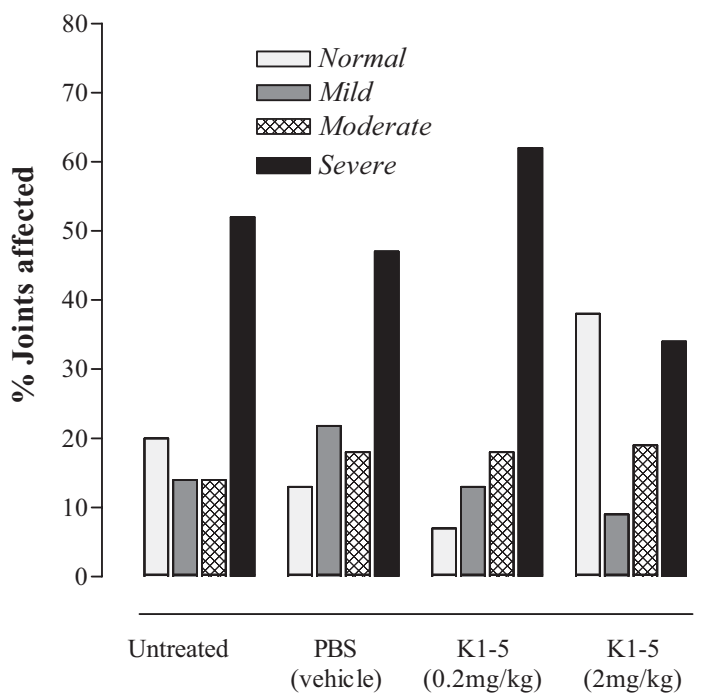

Treatment groups
Protease-activated kringles 1-5 (K1-5) does not significantly affect serum anticollagen $\mathrm{IgG}$. From the day of arthritis onset, mice were treated with $(\mathbf{\Lambda})$ vehicle (phosphate-buffered saline [PBS]; $n=15$ ), (○) $\mathrm{K} 1-5$ at a dose of $0.2 \mathrm{mg} / \mathrm{kg}(n=8)$ or $(\bullet) \mathrm{K} 1-5$ at a dose of $2 \mathrm{mg} / \mathrm{kg}(n=13)$, or $(\square)$ were left untreated $(n=14)$. Serum anticollagen $\lg G$ was measured on day 10 of arthritis and is expressed as arbitrary units $/ \mathrm{ml}$, with reference to pooled serum from mice killed on day 10 of arthritis. Data were analyzed by one-way analysis of variance with Newman-Keul post-test for multiple comparisons: $P>0.10$ for all comparisons.

the first metatarsal and tarsal joints, the differences were less pronounced and did not achieve statistical significance.

Examples of the histological appearance of joints following different treatments are shown in Fig. 5. The joints in untreated animals, and animals treated with vehicle and $0.2 \mathrm{mg} / \mathrm{kg} \mathrm{K1-5}$ exhibited a thickened synovium with a large number of infiltrating cells, together with invasion and erosion of bone by the synovium. Joint space narrowing and necrosis are evident. In contrast, joints from animals treated with $\mathrm{K} 1-5$ at $2 \mathrm{mg} / \mathrm{kg}$ were relatively normal in appearance, with well preserved joint architecture.

Figure 4 illustrates the effect of $\mathrm{K} 1-5$ on the percentage of joints exhibiting no change, or mild, moderate or severe destruction and inflammation. In mice treated with $2 \mathrm{mg} / \mathrm{kg}$ $\mathrm{K} 1-5$ there was a reduction in the percentage of severely affected joints (34\%) relative to untreated (52\%) and PBStreated $(47 \%)$ animals. There was also an increase in the number of joints in which the cartilage and bone architecture at joint interfaces appeared normal. For example, 18 out of $47(38 \%)$ examined joint sections from mice treated with $\mathrm{K} 1-5$ exhibited no destruction of bone or cartilage.
Administration of protease-activated kringles 1-5 (K1-5) reduces joint destruction in collagen-induced arthritis. From the day of arthritis onset, mice were treated intraperitoneally each day with vehicle (phosphatebuffered saline [PBS]; $n=15), \mathrm{K} 1-5$ at a dose of $0.2 \mathrm{mg} / \mathrm{kg}(n=8)$ or $\mathrm{K} 1-5$ at a dose of $2 \mathrm{mg} / \mathrm{kg}(n=13)$, or were left untreated $(n=8)$. On day 10 of arthritis, paws were fixed and stained with haematoxylin and eosin for histological assessment. Data are expressed as percentages of joints exhibiting normal, mild, moderate and severe inflammation and bone/cartilage degradation. Data were analyzed using $\chi^{2}$ test for trend: $P<0.001$ for mice treated with $2 \mathrm{mg} / \mathrm{kg} \mathrm{K} 1-5$, versus untreated mice and mice treated with $0.2 \mathrm{mg} / \mathrm{kg} \mathrm{K} 1-5 ; P<0.01$ for mice treated with $2 \mathrm{mg} / \mathrm{kg} \mathrm{K} 1-5$, versus vehicle-treated mice.

from untreated animals $(P<0.05$, versus $\mathrm{K} 1-5)$ and 7 out of $55(13 \%)$ paws from PBS-treated animals $(P<0.05)$. As expected, given the lack of clinical efficacy, intraperitoneal treatment with the lower dose of $0.2 \mathrm{mg} / \mathrm{kg} \mathrm{K1-5}$ was without significant effect on joint destruction $(62 \%$ severely affected joints, 7\% normal joints).

\section{Discussion}

New blood vessel formation serves to supply oxygen and nutrients to the developing synovium in RA. Targeting the angiogenic process in RA should thus potentially reduce joint inflammation and synovial hyperplasia. Animal models have been extensively used to evaluate the therapeutic potential of antiangiogenic approaches. Broadly acting angiogenesis inhibitors have been described to reduce disease in several rodent models. For example, AGM-1470 (TNP-470), a synthetic derivative of fumagillin, reduced rat $\mathrm{CIA}$ as well as the severity of spontaneous polyarthritis in the KRN/NOD transgenic mouse [13-15,18]. Recently, studies from our own group using the murine CIA model showed that soluble VEGF receptor 1 reduced disease severity when injected intraperi- 


\begin{tabular}{|c|c|c|c|c|}
\hline & Normal & Mild & Moderate & Severe \\
\hline \multicolumn{5}{|l|}{ Distal phalanx joints } \\
\hline Untreated* & $0(0 \%)$ & $3(60 \%)$ & $2(40 \%)$ & $0(0 \%)$ \\
\hline Vehicle & $3(37 \%)$ & $0(0 \%)$ & $4(50 \%)$ & $1(13 \%)$ \\
\hline $\mathrm{K} 1-50.2 \mathrm{mg} / \mathrm{kg}$ ** & $0(0 \%)$ & $2(33 \%)$ & $1(17 \%)$ & $3(50 \%)$ \\
\hline $\mathrm{K} 1-52 \mathrm{mg} / \mathrm{kg}$ & $6(86 \%)$ & $0(0 \%)$ & $1(14 \%)$ & $0(0 \%)$ \\
\hline \multicolumn{5}{|l|}{ Proximal phalanx joints } \\
\hline Untreated & $4(25 \%)$ & $2(12 \%)$ & $2(12 \%)$ & $8(50 \%)$ \\
\hline Vehicle $^{\star}$ & $1(6 \%)$ & $4(27 \%)$ & $0(0 \%)$ & $10(67 \%)$ \\
\hline $\mathrm{K} 1-50.2 \mathrm{mg} / \mathrm{kg}^{\star \star}$ & $1(8 \%)$ & $1(8 \%)$ & $0(0 \%)$ & $10(83 \%)$ \\
\hline $\mathrm{K} 1-52 \mathrm{mg} / \mathrm{kg}$ & $7(54 \%)$ & $2(15 \%)$ & $1(8 \%)$ & $3(23 \%)$ \\
\hline \multicolumn{5}{|l|}{ First metatarsal joints } \\
\hline Untreated & $4(25 \%)$ & $1(6 \%)$ & $1(6 \%)$ & $10(63 \%)$ \\
\hline Vehicle & $1(5 \%)$ & $5(28 \%)$ & $3(17 \%)$ & $9(50 \%)$ \\
\hline $\mathrm{K} 1-50.2 \mathrm{mg} / \mathrm{kg}$ & $1(7 \%)$ & $3(20 \%)$ & $2(13 \%)$ & $9(60 \%)$ \\
\hline $\mathrm{K} 1-52 \mathrm{mg} / \mathrm{kg}$ & $3(20 \%)$ & $1(7 \%)$ & $3(20 \%)$ & $8(53 \%)$ \\
\hline \multicolumn{5}{|l|}{ Tarsal joints } \\
\hline Untreated & $2(15 \%)$ & $1(7 \%)$ & $2(15 \%)$ & $8(62 \%)$ \\
\hline Vehicle & $2(14 \%)$ & $3(21 \%)$ & $3(21 \%)$ & $6(43 \%)$ \\
\hline $\mathrm{K} 1-50.2 \mathrm{mg} / \mathrm{kg}$ & $1(8 \%)$ & $0(0 \%)$ & $5(42 \%)$ & $6(50 \%)$ \\
\hline $\mathrm{K} 1-52 \mathrm{mg} / \mathrm{kg}$ & $2(17 \%)$ & $1(8 \%)$ & $4(33 \%)$ & $5(42 \%)$ \\
\hline
\end{tabular}

Mice were treated with vehicle (phosphate-buffered saline [PBS]) or protease-activated kringles 1-5 (K1-5) at a dose of either $0.2 \mathrm{mg} / \mathrm{kg}$ or $2 \mathrm{mg} / \mathrm{kg}$, or were left untreated. On day 10 of arthritis, paws were fixed and stained with haematoxylin and eosin for histological assessment of distal phalanx, proximal phalanx, first metatarsal and tarsal joints. Data were analyzed using $\chi^{2}$ test for trend: ${ }^{*} P<0.05$, ${ }^{\star \star} P<0.01$, versus mice treated with $2 \mathrm{mg} / \mathrm{kg} \mathrm{K} 1-5$.

toneally every day for the first 5 days after disease onset [19]. Similar results were obtained using anti-VEGF antibodies $[20,21]$. More recently, an antibody against VEGF receptor 1 suppressed angiogenesis and joint destruction in CIA when given before disease onset [31]. Interestingly, anti-VEGF receptor 1 antibody reduced mobilization of bone marrow derived myeloid progenitors into the peripheral blood, suggesting that part of the mechanism of action in that study was impairment in leucocyte infiltration.

These observations demonstrate that inhibition of angiogenesis suppresses arthritis in animal models. In terms of the effect on CIA of endogenously generated angiogenic inhibitors, a very recent report indicated that angiostatin can delay the onset of CIA in DBA/1 mice [32]. In that study, fibroblasts, transduced with angiostatin-expressing retroviral vectors, were transplanted into the knee before the onset of arthritis or macroscopic signs of arthritis. Angiostatin was found to reduce pannus formation and angiogenesis. Other studies have reported that endostatin, a $20 \mathrm{kDa}$ fragment of collagen XVIII, can also reduce disease. Using a model in which human RA tissue is grafted into severe combined immunodeficiency mice, it was shown that intrasynovial injection of human recombinant endostatin reduced both the volume of the grafted synovium and the number of vessels [33]. Similarly, endostatin-expressing lentivirus injected directly into the joints of human TNF transgenic mice before the onset of disease reduced synovial blood vessel density and arthritis severity [34].

In the present study we examined the effect on CIA of $\mathrm{K} 1-5$ - an angiogenesis inhibitor that is structurally related to angiostatin. In common with angiostatin, $\mathrm{K} 1-5$ contains four of the disulphide-linked kringle domains of plasminogen, but it also includes most of $\mathrm{K} 5$ - a potent inhibitor of endothelial cell proliferation $[26,27]$. We chose to administer $\mathrm{K} 1-5$ after the onset of macroscopic signs of arthritis because we believe that this therapeutic approach is more relevant to the treatment of RA than the preventive regimen utilized in other studies [32,34]. The relevance of this methodology has been demonstrated using anti-TNF- $\alpha$ antibody, which was first shown to ameliorate CIA [28], and was then proven to be clinically effective for the treatment of human RA [29].

We report here that intraperitoneal administration of $\mathrm{K} 1-5$ significantly reduces disease severity in an acute model of established arthritis. This dose-dependent amelioration in the severity of disease was observed for both the clinical score (an index of disease severity and the number of affected paws) and for paw swelling. Histological examination of all joints from the hind feet of mice treated with K1-5 revealed a significant degree of joint protection when compared with vehicle-treated or with untreated mice groups. A comparable amelioration of CIA (reduced footpad swelling, clinical score, bone/cartilage destruction 


\section{Figure 5}

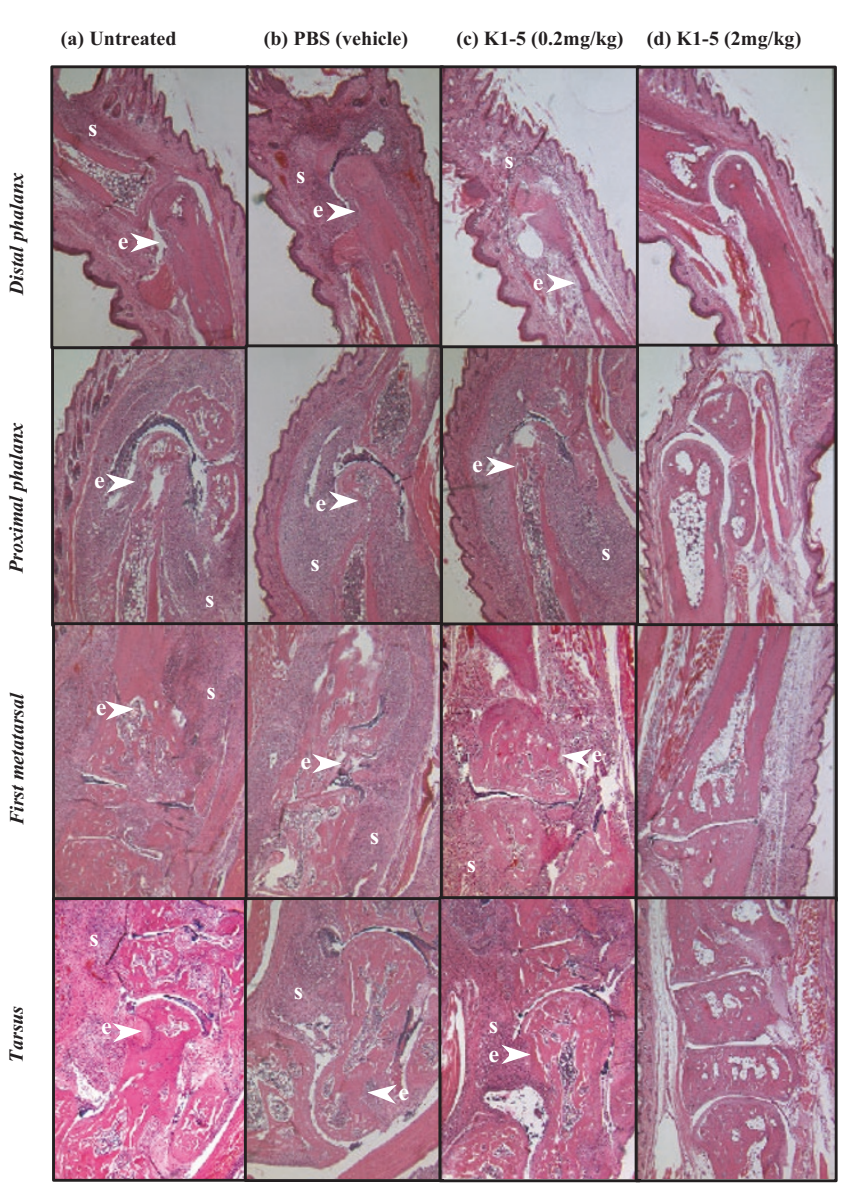

Histological appearance of joints after administration of proteaseactivated kringles 1-5 (K1-5). Haematoxylin and eosin stained sections of distal phalanx, proximal phalanx, first metatarsal and tarsus joints from (a) untreated mice, (b) vehicle (phosphate buffered saline [PBS])-treated mice, and animals receiving $\mathrm{K} 1-5$ at a daily intraperitoneal dose of either (c) $0.2 \mathrm{mg} / \mathrm{kg}$ or (d) $2 \mathrm{mg} / \mathrm{kg}$. All sections were obtained on day 10 of arthritis. Magnification $\times 40$. s, synovium; e, bone erosions.

and synovitis) was observed when $\mathrm{K} 1-5$ was administered subcutaneously at a daily dose of $2.5 \mathrm{mg} / \mathrm{kg}$ (data not shown). We propose that K1-5 mediates its actions in CIA by preventing the formation of new vessels in the proliferating synovium of the inflamed joints. This is supported by data showing that $\mathrm{K} 1-5$ significantly reduced fibroblast growth factor-2-induced neovascularization in the mouse corneal micropocket assay and reduced angiogenesis in chicken embryos. Moreover, K1-5 significantly suppressed tumour growth and microvessel density of a murine fibrosarcoma [27]. We have also observed inhibition of fibroblast growth factor-2-driven proliferation of the murine endothelial cell line Py4-1 (data not shown).

The mechanism of action of $\mathrm{K} 1-5$ is at present unknown, of angiostatin. Angiostatin has been shown to induce apoptosis in endothelial cells selectively [35]. A subsequent study showed that angiostatin blocks invasion of tissue plasminogen activator-producing endothelial and melanoma cells [36]. In another study, the $\alpha / \beta$ subunits of ATP synthase were identified as an angiostatin binding site on human umbilical vein endothelial cells. It was proposed that the binding of angiostatin to plasma membrane-localized ATP synthase may disrupt production of ATP and render endothelial cells more vulnerable to irreversible cell damage [37]. Angiostatin has also been found to inhibit migration of monocytes and neutrophils in response to the chemokines interleukin-8, macrophage inflammatory protein- 2 and growth-regulating oncogene $\alpha$, with both the $\mathrm{K} 1-4$ and $\mathrm{K} 1-3$ forms being active. Angiostatin also inhibited chemokine-induced angiogenesis in vivo, in parallel with a reduction in the number of recruited leucocytes [38]. Thus, in addition to the antiangiogenic activity of angiostatin and $\mathrm{K} 1-5$, it is possible that these molecules might exert anti-inflammatory effects as well. Recently, bovine arterial endothelial cells were shown to adhere to angiostatin in an $\alpha_{v} \beta_{3}$ integrin dependent manner. Of particular relevance to the present study, $\mathrm{K} 1-3$ and $\mathrm{K} 1-5$, but not plasminogen, were shown to bind to $\alpha_{v} \beta_{3}$ integrin [39]. Thus, $\mathrm{K} 1-5$ might reduce angiogenesis by interfering with $\alpha_{v} \beta_{3}$-mediated signal transduction.

\section{Conclusion}

K1-5 appears to be an effective therapeutic agent in murine CIA, most probably due to reduced synovial infiltration and inflammation subsequent to decreased synovial vascularity. Although we were unable to show complete reversal of the clinical signs of arthritis, a very significant degree of joint protection was observed in mice treated with K1-5. In RA, it has been suggested that established therapies such as TNF- $\alpha$ blockade might predispose to infections. This is not likely, in theory at least, to be a side effect of antiangiogenic treatments, and hence combination of TNF- $\alpha$ inhibition and angiogenesis blockade may be beneficial, without augmenting potential adverse effects.

\section{Acknowledgements}

The Kennedy Institute of Rheumatology Division receives a core grant from ARC. The authors are grateful to Paul Warden and the staff of the Biological Services Unit for care and maintenance of the animals, and to Mr P Connolly for histology. All research was performed in accordance with the guidelines of the Kennedy Institute of Rheumatology Ethical Review Process Committee and the Home Office Guidance on the Operation of the Animals (Scientific Procedures) Act 1986 (PPL70/4158).

\section{References}

1. Feldmann M, Brennan FM, Maini RN: Rheumatoid arthritis. Cell 1996, 85:307-310.

2. Paleolog EM: Angiogenesis: a critical process in the pathogenesis of RA: a role for VEGF? Br J Rheumatol 1996, 35:917-919.

3. Koch AE: Review: angiogenesis: implications for rheumatoid arthritis. Arthritis Rheum 1998, 41:951-962.

4. Paleolog EM, Fava RA: Angiogenesis in rheumatoid arthritis: implications for future therapeutic strategies. Springer Semin Immunopathol 1998, 20:73-94. 
5. Fava RA, Olsen NJ, Spencer-Green G, Yeo KT, Yeo TK, Berse B, Jackman RW, Senger DR, Dvorak HF, Brown LF: Vascular permeability factor/endothelial growth factor (VPF/VEGF): accumulation and expression in human synovial fluids and rheumatoid synovial tissue. J Exp Med 1994, 180:341-346.

6. Koch AE, Harlow LA, Haines GK, Amento EP, Unemori EN, Wong WL, Pope RM, Ferrara N: Vascular endothelial growth factor. A cytokine modulating endothelial function in rheumatoid arthritis. J Immunol 1994, 152:4149-4156.

7. Nagashima M, Yoshino S, Ishiwata T, Asano G: Role of vascular endothelial growth factor in angiogenesis of rheumatoid arthritis. J Rheumatol 1995, 22:1624-1630.

8. Paleolog EM, Young S, Stark AC, McCloskey RV, Feldmann M, Maini RN: Modulation of angiogenic vascular endothelial growth factor by tumor necrosis factor alpha and interleukin-1 in rheumatoid arthritis. Arthritis Rheum 1998, 41:1258-1265.

9. Ballara SC, Taylor PC, Reusch P, Marmé D, Feldmann M, Maini RN, Paleolog EM: Raised serum vascular endothelial growth factor levels are associated with destructive change in inflammatory arthritis. Arthritis Rheum 2001, 44:2055-2064.

10. Blake DR, Merry P, Unsworth J, Kidd BL, Outhwaite JM, Ballard R, Morris CJ, Gray L, Lunec J: Hypoxic-reperfusion injury in the inflamed human joint. Lancet 1989, 1:289-293.

11. Paleolog EM, Miotla JM: Angiogenesis in arthritis: role in disease pathogenesis and as a potential therapeutic target. Angiogenesis 1998, 2:295-307.

12. Ballara SC, Miotla JM, Paleolog EM: New vessels, new approaches: angiogenesis as a therapeutic target in musculoskeletal disorders. Int J Exp Pathol 1999, 80:235-250.

13. Peacock DJ, Banquerigo ML, Brahn E: Angiogenesis inhibition suppresses collagen arthritis. J Exp Med 1992, 175:11351138.

14. Oliver SJ, Banquerigo ML, Brahn E: Suppression of collageninduced arthritis using an angiogenesis inhibitor, AGM-1470, and a microtubule stabilizer, taxol. Cell Immunol 1994, 157: 291-299.

15. Oliver SJ, Cheng TP, Banquerigo ML, Brahn E: Suppression of collagen-induced arthritis by an angiogenesis inhibitor, AGM1470 , in combination with cyclosporin: reduction of vascular endothelial growth factor (VEGF). Cell Immunol 1995, 166: 196-206.

16. Arsenault AL, Lhotak S, Hunter $\mathrm{WL}$, Banquerigo ML, Brahn $\mathrm{E}$ : Taxol involution of collagen-induced arthritis: ultrastructural correlation with the inhibition of synovitis and neovascularization. Clin Immunol Immunopathol 1998, 86:280-289.

17. Oliver SJ, Cheng TP, Banquerigo ML, Brahn E: The effect of thalidomide and 2 analogs on collagen induced arthritis. $J$ Rheumatol 1998, 25:964-969.

18. de Bandt M, Grossin M, Weber AJ, Chopin M, Elbim C, Pla M, Gougerot-Pocidalo MA, Gaudry M: Suppression of arthritis and protection from bone destruction by treatment with TNP470/AGM-1470 in a transgenic mouse model of rheumatoid arthritis. Arthritis Rheum 2000, 43:2056-2063.

19. Miotla J, Maciewicz R, Kendrew J, Feldmann M, Paleolog E: Treatment with soluble VEGF receptor reduces disease severity in murine collagen-induced arthritis. Lab Invest 2000, 80:11951205.

20. Lu J, Kasama T, Kobayashi K, Yoda Y, Shiozawa F, Hanyuda M, Negishi M, Ide H, Adachi M: Vascular endothelial growth factor expression and regulation of murine collagen-induced arthritis. J Immuno/ 2000, 164:5922-5927.

21. Sone H, Kawakami $Y$, Sakauchi M, Nakamura Y, Takahashi A, Shimano H, Okuda Y, Segawa T, Suzuki H, Yamada N: Neutralization of vascular endothelial growth factor prevents collagen-induced arthritis and ameliorates established disease in mice. Biochem Biophys Res Commun 2001, 281:562-568.

22. Cao $Y$ : Endogenous angiogenesis inhibitors and their therapeutic implications. Int J Biochem Cell Biol 2001, 33:357-369.

23. O'Reilly MS, Holmgren L, Shing Y, Chen C, Rosenthal RA, Moses M, Lane WS, Cao Y, Sage EH, Folkman J: Angiostatin: a novel angiogenesis inhibitor that mediates the suppression of metastases by a Lewis lung carcinoma. Cell 1994, 79:315-328.

24. Sim BK, MacDonald NJ, Gubish ER: Angiostatin and endostatin: endogenous inhibitors of tumor growth. Cancer Metastasis Rev 2000, 19:181-190.

25. Cao Y, Ji RW, Davidson D, Schaller J, Marti D, Sohndel S, McCance SG, O'Reilly MS, Llinas M, Folkman J: Kringle domains of human angiostatin. Characterization of the anti-proliferative activity on endothelial cells. J Biol Chem 1996, 271: 29461-29467.

26. Cao Y, Chen A, An SS, Ji RW, Davidson D, Llinas M: Kringle 5 of plasminogen is a novel inhibitor of endothelial cell growth. $J$ Biol Chem 1997, 272:22924-22928.

27. Cao R, Wu HL, Veitonmaki N, Linden P, Farnebo J, Shi GY, Cao $Y$ : Suppression of angiogenesis and tumor growth by the inhibitor K1-5 generated by plasmin-mediated proteolysis. Proc Natl Acad Sci USA 1999, 96:5728-5733.

28. Williams RO, Feldmann M, Maini RN: Anti-tumor necrosis factor ameliorates joint disease in murine collagen-induced arthritis. Proc Natl Acad Sci USA 1992, 89:9784-9788.

29. Maini RN, Taylor PC, Paleolog E, Charles P, Ballara S, Brennan FM, Feldmann M: Anti-tumour necrosis factor specific antibody (infliximab) treatment provides insights into the pathophysiology of rheumatoid arthritis. Ann Rheum Dis 1999, 58(suppl I): $156-160$.

30. Miller EJ: Structural studies on cartilage collagen employing limited cleavage and solubilization with pepsin. Biochemistry 1972, 11:4903-4909.

31. Luttun A, Tjwa M, Moons L, Wu Y, Angelillo-Scherrer A, Liao F, Nagy JA, Hooper A, Priller J, De Klerck B, Compernolle V, Daci E, Bohlen P, Dewerchin M, Herbert JM, Fava R, Matthys P, Carmeliet G, Collen D, Dvorak HF, Hicklin DJ, Carmeliet P: Revascularization of ischemic tissues by PIGF treatment, and inhibition of tumor angiogenesis, arthritis and atherosclerosis by anti-FIt1. Nat Med 2002, 8:831-840.

32. Kim JM, Ho SH, Park EJ, Hahn W, Cho H, Jeong JG, Lee YW, Kim $\mathrm{S}$ : Angiostatin gene transfer as an effective treatment strategy in murine collagen-induced arthritis. Arthritis Rheum 2002, 46 : 793-801.

33. Matsuno H, Yudoh K, Uzuki M, Nakazawa F, Sawai T, Yamaguchi $\mathrm{N}$, Olsen BR, Kimura T: Treatment with the angiogenesis inhibitor endostatin: a novel therapy in rheumatoid arthritis. $J$ Rheumatol 2002, 29:890-895.

34. Yin G, Liu W, An P, Li P, Ding I, Planelles V, Schwarz EM, Min W: Endostatin gene transfer inhibits joint angiogenesis and pannus formation in inflammatory arthritis. Mol Ther 2002, 5: 547-554.

35. Lucas R, Holmgren L, Garcia I, Jimenez B, Mandriota SJ, Borlat F, Sim BK, Wu Z, Grau GE, Shing Y, Soff GA, Bouck N, Pepper MS: Multiple forms of angiostatin induce apoptosis in endothelial cells. Blood 1998, 92:4730-4741.

36. Stack MS, Gately S, Bafetti LM, Enghild JJ, Soff GA: Angiostatin inhibits endothelial and melanoma cellular invasion by blocking matrix-enhanced plasminogen activation. Biochem J 1999, 340:77-84.

37. Moser TL, Stack MS, Asplin I, Enghild JJ, Hojrup P, Everitt L, Hubchak S, Schnaper HW, Pizzo SV: Angiostatin binds ATP synthase on the surface of human endothelial cells. Proc Natl Acad Sci USA 1999, 96:2811-2816.

38. Benelli R, Morini M, Carrozzino F, Ferrari N, Minghelli S, Santi L, Cassatella M, Noonan DM, Albini A: Neutrophils as a key cellular target for angiostatin: implications for regulation of angiogenesis and inflammation. FASEB J 2002, 16:267-269.

39. Tarui T, Miles LA, Takada Y: Specific interaction of angiostatin with integrin alpha(v)beta(3) in endothelial cells. J Biol Chem 2001, 276:39562-39568.

\section{Correspondence}

Dr Ewa Paleolog, Kennedy Institute of Rheumatology Division, Faculty of Medicine, Imperial College of Science, Technology and Medicine, Arthritis Research Campaign Building, 1 Aspenlea Road, London W6 8LH, UK. Tel: +44 208383 4481; fax: +44 208383 4499; e-mail: e.paleolog@ic.ac.uk 